\title{
David Oliver: Silencing NHS staff who speak out is sheer stupidity
}

\author{
David Oliver consultant in geriatrics and acute general medicine
}

Berkshire

Amid a global pandemic, which is putting our health services and frontline staff under immense strain and personal risk, is it right to suppress their free speech?

On 31 March the media reported on a dossier from the Doctors' Association UK detailing numerous instances of medical and nursing staff being warned, disciplined, threatened, monitored, and gagged for speaking out on social or mainstream media. ${ }^{1}$

Their concerns included a lack of personal protective equipment and testing for covid-19- putting them, their families, and their patients at risk. ${ }^{2}$ The staff also highlighted what they saw as inconsistent and unconvincing guidance from their employers and national authorities.

There's a long history of NHS executives and managers being leant on to prevent them speaking out publicly about other issues, such as serious overcrowding and bed pressures in winter. Speaking to the Guardian's Denis Campbell about the Doctors' Association report, an NHS England spokesperson emphasised the importance of consistent, clear, centralised official communication during a major national incident but said that individual staff members remained free to speak out in a personal capacity. ${ }^{1}$

So, what are the rights and wrongs here? Clinical staff should generally adhere to the social media guidance set out by organisations such as the General Medical Council or the BMA. ${ }^{34}$ Compromising patient confidentiality by discussing identifiable details or recent cases could cause considerable distress. Abusive comments towards professional colleagues, incitement of hatred or bullying, or inappropriate online interactions with patients are all clearly liable to sanction, with good reason.

NHS employment contracts often contain clauses about communications that may compromise or threaten the reputation of the employing organisation. Here, however, we're talking about staff putting their own safety on the line every day through close contact with infected patients, while worrying about their own health or risks to their families. Many have signed up for a much heavier shift pattern or radical changes to their job or job plan—often involving work in unfamiliar disciplines or situations, enhancing their fear and vulnerability.

They're also coping with staffing gaps, as the Royal College of Physicians highlighted recently when it found that around one in four doctors in medical specialties was off sick or in self-isolation. ${ }^{5}$ Clinical staff may experience moral distress ${ }^{6}$ from the change in care standards or visiting arrangements or from the sheer number of sick and dying people around them, many of whom can't be saved and may die without family around them or may speak their last words before intubation.

Added to that mix is a lack of trust in the ability of central agencies to deliver personal protective equipment and testing kits, a failure to keep staff safe, and a huge mismatch between the stark reality seen by staff and the official lines being set out by government agencies and hospitals. Clearly, healthcare staff will speak out, and social media give them a platform to do so.

Of course, we should always get our facts straight before speaking out, and we should understand local and national guidance and plans. We want consistent, evidence based messaging, and we shouldn't mis-represent plans or needlessly scare the public. Nor should we undermine the hard work managers are doing to support frontline staff and patients.

But we should surely have learnt by now from serial scandals of silenced, threatened, and ruined whistleblowers. And we should be mindful of the statutory duty set out by professional regulators: openness, transparency, and candour.

Threatening, disciplining, demoralising, or suspending the very staff we need most to get us through the next few months is a spectacular own goal and reputationally disastrous. It must stop.

Competing interests: See www.bmj.com/about-bmj/freelance-contributors. Provenance and peer review: Commissioned; not externally peer reviewed.

1 Campbell D. NHS staff "gagged" over coronavirus shortages. Guardian 2020 Mar 31. https://www.theguardian.com/society/2020/mar/31/nhs-staff-gagged-over-coronavirusprotective-equipment-shortages.

$2 \quad$ Illman J, Discombe M. Exclusive: Staff in "near revolt" over protective gear crisis. Health Serv J 2020 Mar 24. https://www.hsj.co.uk/policy-and-regulation/exclusive-staff-in-nearrevolt-over-protective-gear-crisis/7027216. article. 
3 General Medical Council. Doctors' use of social media. 22 Apr 2013. https://www.gmcuk.org/ethical-guidance/ethical-guidance-for-doctors/doctors-use-of-social-media.

4 BMA. Social media, ethics and professionalism. Guidance for doctors. 2017. https://www. bma.org.uk/-/media/files/pdfs/employment\%20advice/ethics/ethics\%20guidance\%20on\% 20social\%20media\%20final.pdf.

5 Stubley P. Coronavirus: One in four NHS doctors off sick or in isolation, says leading medic. Independent $2020 \mathrm{Mar} 31$. https://www.independent.co.uk/news/health/coronavirusdoctors-sick-isolation-cases-nhs-andrew-goddard-rcp-a9435411.html.
6 Greenberg N, Docherty M, Gnanapragasam S, Wessely S. Managing mental health challenges faced by healthcare workers during covid-19 pandemic. BMJ 2020;368:m1211. 10.1136/bmj.m1211 32217624

Published by the BMJ Publishing Group Limited. For permission to use (where not already granted under a licence) please go to http://group.bmj.com/group/rights-licensing/ permissions 